\title{
SOLUSI PENGEMBANGAN UMKM MELALUI ONTOLOGI
}

\author{
Oleh: \\ Irwan Susanto ${ }^{1)}$ \\ Email: irwansusanto_yk@yahoo.com \\ ${ }^{1)}$ Dosen Sekolah Tinggi Teknologi Telematika Telkom
}

\begin{abstract}
SMEs proved as the most contributor $(92.71 \%)$ to the Indonesian employment. Ironically SMEs have many problems. Several attempts were employed, but they were unsucceessful. This article reached the problem solution through onthological philosophy as the novelty. Through descriptive analysis, SMEs were viewed from four dimensions (quantity, autonomy-correlation, dynamic of the process, meaning-value). The result of the study of onthology that described the reality of SMEs Indonesian context is the concept of businesses activities which cannot stand alone. It must correlate with the government and the environment and society and proceed dynamically to adjust to the environment that is formed from the value of the nation's character (togetherness, brotherhood, mutual cooperation). The implications of onthology are the concept of SME development that should be based on the character of SMEs. SMEs still need protection and proactive support on both micro-businesses and macro-businesses aspect of SMEs, by all stakeholders such as government, business associations, universities. To make SMEs grow, it needs government's integrated policies that can encourage the development of SMEs.
\end{abstract}

Keywords: ontologi, dimensi ontologi, nilai, karakter.

\section{PENDAHULUAN}

Pertumbuhan ekonomi dapat diartikan sebagai proses perubahan kondisi perekonomian suatu negara secara berkesinambungan menuju keadaan yang lebih baik selama periode tertentu. Pertumbuhan ekonomi dapat diartikan juga sebagai proses kenaikan kapasitas produksi suatu perekonomian yang diwujudkan dalam bentuk kenaikan pendapatan nasional [BPS, 2014].

Laporan World Bank, 2014, menggambarkan pertumbuhan ekonomi yang kuat di Indonesia telah membantu menekan angka kemiskinan. Angka kemiskinan turun ke $11.3 \%$ pada tahun 2014, dibandingkan 24\% pada tahun
1999. Beberapa penelitian menggambarkan peran UMKM terhadap perekonomian, diantaranya memberikan kontribusi yang signifikan dalam penyerapan tenaga kerja, menyumbang Produk Domestik Bruto, dan nilai ekspor nasional dan investasi nasional, (Sudarto et al. 2013). Data BPS tahun 2014, menunjukkan jumlah usaha mikro tahun 2013 sebanyak 2.887. 015 usaha kecil sebanyak 531. 351. UMKM menyerap 99\% tenaga kerja dan menyumbang 55\% PDB. (Sudarto et al. 2013)

Ironisnya, potensi besar UMKM di Indoensia tersebut, belum dapat tergali dengan maksimal, bahkan sering manghadapi masalah. Beberapa permasalahan baik yang bersumber dari aspek 
internal maupun eksternal yang sering dijumpai UMKM. Permasalahan dari aspek internal diantaranya: kualitas sumber daya manusia rendah, rendah dalam pemanfaatan teknologi, keterbatasan dalam akses informasi, daya beli bahan baku rendah (Ramdhansyah \& Silalahi 2013) (Glisovic \& Martinez 2012) (Komarudin 2014) (Fang et al. 2013) (Suandi \& Susilo 2011). Permasalahan karena aspek eksternal diantaranya kesulitan dalam mendapatkan sumber pendanaan terutama dari perbankan, iklim usaha yang tidak menunjang, tidak mampu menembus pasar ekspor, ancaman pasar global (Suyatna n.d.), kurangnya dukungan pihak eksternal dalam mendukung UMKM, kebijakan pemerintah kurang kondusif (Suandi \& Susilo 2011).

Kesulitan memperoleh sumber pendanaan dari bank dikarenakan: rendahnya akses informasi UMKM terhadap layanan per-bankan, prosedur dan persyaratan perbankan relatif rumit bagi UMKM sehingga tidak mampu mendapatkan pinjaman, tingkat bunga pinjaman relatif tinggi, kurangnya pembinaan dalam manajemen keuangan. Salah satu langkah UMKM mengatasi kesulitan adalah dengan menggunakan modal sendiri (Suryana 2012) meskipun terbatas atau memilih jalan alternatif untuk mendapatkan dana yaitu dengan mendapatkan sumber modal dari peminjaman kepada lembaga non formal. Bagi UMKM langkah ini ditempuh karena mereka mendapatkan kemudahan dan prosesnya relatif cepat, meskipun tingkat bunganya relatif tinggi. Keterbatasan mendapatkan akses modal dan minimnya modal yang dimiliki, menyebabkan UMKM tidak mampu mengem- bangkan bisnisnya, meningkatkan revenue, daya beli rendah, hanya mampu mempekerjakan SDM dengan kompetensi rendah (Suryana 2012).

Beberapa usaha Pemerintah terkait dengan keberlangusngan hidup UMKM telah dilakukan, diantaranya untuk menciptakan iklim usaha, pembinaan dan pengembangan, memberikan perlindungan bagi pelaku UMKM, mewujudkan masyarakat adil dan makmur melalui perangkat hukum seperti UU no 9 tahun 1995, PP no 4 tahun 1997, PP no 32 tahun 1998, INPRES no 10 tahun 1999, Keppres no 127 tahun 2001, Keppres no 56 tahun 2002 dan UU no 20 tahun 2008.

\section{TELAAH PUSTAKA}

Memandang fenomena nasib ironis UMKM, para peneliti, akademisi, praktisi menggulirkan beberapa hasil karya pemikiran, penelitian maupun ide pemecahan masalah. Beberapa diantaranya mengusulkan pemecahan melalui accounting (Muhammad \& Kusuma 2014); rumusan strategi terapan pengembangan UMKM (Suandi \& Susilo 2011), (Abidin n.d.) (Suyatna n.d.) (Rumanti \& Syauta 2013) (Hamid 2010). Sebagian lagi mencoba dengan pendekatan SDM, sistem informasi dan teknologi (Haryani n.d.) (Purnomo 2011) (Ahmad Mardalis, M. Sholahuddin n.d.) (Khhotimah \& Fiati 2013); sistem kemitraan (Kasus et al. 2011); program HAKI (Sinaga 2013); program sistem financial support (Suryana 2012) (Ramdhansyah \& Silalahi 2013); analisa potensi (Sudarto et al. 2013); pengembangan produk (Fadland et al. 2013). Semua pendekatan pemecahan masalah yang ditawarkan bersifat pemecahan terapan dan sektoral. Belum ada yang melakukan pendekatan melalui telaah hakekat UMKM dan per- 
masalahannya yaitu melalui filsafat ontologi, sehingga dapat diidentifikasi UMKM yang sejatinya beserta dengan permasalahannya. Artikel ini melakukan telaah dengan pendekatan filsafat ontologi, sehingga kebaruan dari artikel ini adalah pendekatan ontologi.

\section{RUMUSAN MASALAH:}

Berdasarkan pada latar belakang, maka rumusan masalah dalam makalah ini adalah:

1. Apa hakekat ontologi Usaha Mikro Kecil Menengah dalam konteks di Indonesia?

2. Apa makna dimensi ontologi Usaha Mikro Kecil Menengah dalam konteks di Indonesia?

\section{TUJUAN:}

1. Menemukan makna dimensi ontologi usaha Mikro Kecil Menengah dalam konteks di Indonesia

2. Diharapkan dari pendefinisian secara ontologi, dapat menjadi pijakan untuk mengurai permasalahan lambatnya perkembangan usaha Mikro Kecil Menengah di Indonesia, dan menemukan solusinya.

Metode analisa yang digunakan dalam makalah ini adalah deskriptif. Dalam makalah ini dibahas UMKM dalam konteks Indonesia ditinjau dari dimensi ontologi. Pendekatan telaah meliputi: Pertama, tinjauan kuantitas keberadaan obyek merupakan realitas tunggal atau jamak. telaah ini menjadi telaah mendasar dalam mendefinisikan obyek yang ditinjau. Kedua tinjauan telaah sifat obyek, yaitu obyek bersifat materi atau idealisme.(Moon 2006) Ketiga tinjauan telaah proses, kejadian, perubahan obyek. Telaah ini akan memberikan gambaran apakah obyek merupakan realita dinamis atau statis. Obyek material dalam makalah ini adalah konsep pengembangan bisnis, yang dalam hal ini dikhususkan pada Usaha Mikro Kecil Menengah. Sedangkan obyek formal dalam penelitian ini adalah kajian aspek ontologi.

\section{PENGERTIAN ONTOLOGI DAN ONTOLOGI BISNIS}

Ontologi merupakan salah satu dari tiga pilar filsafat, yaitu ontologi, epistemologi dan aksiologi. Dalam perbincangan kefilsafatan ontologi sering disamakan dengan istilah metafisika. Metafisika barasal dari istilah Yunani $t a$ meta ta physika, artinya "sesudah atau di belakang relitas fisik". Ontologi berasal dari bahasa Yunani, yaitu dari kata on atau ontos yang berarti "yang ada" dan logos yang berarti 'ilmu'. Secara etimologi berarti ilmu yang mempelajari apa yang ada.

Istilah ontologi banyak digunakan pada saat membahas konteks filsafat ilmu. Onotologi membahas tentang apa yang ingin kita ketahui, seberapa jauh kita ingin tahu, atau dengan kata lain suatu kajian mengenai teori tentang "sesuatu yang ada". [Suryasumantri (1985)](Moon 2006). Ontologi membahas tentang yang ada, universal, yang tidak terikat oleh satu perwujudan tertentu. Ontologi mencari inti yang terkandung dalam setiap kenyataan.

\section{PERSOALAN-PERSOALAN ON- TOLOGI}

Sebagai bagian dari filsafat, ontologi memiliki dua sudut pandang dalam memandang obyek, yaitu sudut pandang obyek material dan obyek formal. Sudut pandang obyek material adalah 
ontologi memandang obyek adalah segala sesuatu 'yang ada'. Sedangkan dari sudut pandang formal, ontologi memandang obyek dari sudut pandang filsafat. Tugas mendasar ontologi adalah menjabarkan gambaran secara umum struktur mendasar dari realitas-realitas dan menyatukannnya ke dalam satu pandangan menyeluruh, sehingga ditemukan satu inti yang mewakilinya. (Sutikna 2013).

Dalam memahami ontologi sebagai filsafat tentang sesuatu 'yang ada', terdapat beberapa cara dalam memandang persoalan. Pertama cara pandang kuantitas. Cara pandang kuantitas merupakan pendekatan untuk menjawab persoalan apakah 'yang ada' itu jamak atau tunggal. Apabila realitas 'yang ada' bersifat tunggal ontologi harus mampu menjelaskan keanekaragaman yang ada, sebaliknya jika realitas 'yang ada' itu jamak, maka ontologi harus mampu menjelaskan hubungan antara entitas satu terhadap yang lain. Kedua, cara pandang dari segi kemandirian, yaitu cara memandang dari sifat otonomi atau korelasi. Ketiga ontologi berusaha mampu menjawab persoalan dinamika 'yang ada', yaitu yang menyangkut realitas 'yang ada' apakah bersifat tetap atau berubah. Keempat, ontologi menyelidiki dari cara pandang sifat jasmani-rohani, yaitu cara pandang yang menjawab pertanyaan apakah realitas 'yang ada' bersifat jasmani atau rohani.

Kelima, cara pandang dari sifat kausalitas, yaitu ontologi menyelidiki persoalan dengan memandang dari hubungan sebab akibat pada realitas 'yang ada'. Cara pandang dimensi kausalitas untuk mengetahui apakah realitas 'yang ada' satu dipengaruhi oleh yang lain; re- alitas 'yang ada' satu mempengaruhi terhadap yang lain; ataukah realitas 'yang ada' satu dengan lainnya saling mempengaruhi. Keenam, cara pandang dari sifat value yang dimiliki dalam realitas 'yang ada'. Cara pandang ini untuk menjawab persoalan apakah realitas 'yang ada' memiliki arti dan nilai. Ketujuh, persoalan ontologi adalah keberadaan sifat normatif. Cara pandang persoalan normatif untuk menyelidiki apakah realitas 'yang ada' mengandung muatan normatif? Apakah realitas 'yang ada' mengandung muatan benar, baik, jelek, palsu? Selanjutnya persoalan ontologi kedelapan, yaitu cara pandang dari dimensi ketiadaan, yaitu cara pandang apakah realita 'yang ada' mengalami ketiadaan. Sifat ketiadaan ini sebagai bentuk negasi dari keberadaan sesuatu.

\section{ALIRAN-ALIRAN ONTOLOGI}

Persoalan 'keberadaan sesuatu' ditinjau aspek ontologi atau teori hakekat, dikenal beberapa aliran dalam:

1. Keberadaan ditinjau aspek kuantitas / jumlah

- Monoisme, paham beranggapan bahwa hakekat keberadaan berasal dari satu saja sebagai sumber asal, baik materi maupun rohani.

- Dualisme, paham yang beranggapan bahwa hakekat kebedaraan berasal dari dua sumber, yaitu hakekat materi dan hakekat ruhani.

- Pluralisme, paham yang beranggapan bahwa hakekat keberadaan berasal dari banyak unsur.

2. Keberadaan ditinjau aspek sifat

- Materialisme, paham yang beranggapan bahwa keberadaan berasal dari sumber materi. 
- Idealisme, paham yang beranggapan bahwa keberadaan berasal dari sumber idea, sesuatu yang hadir dalam jiwa. Faham ini sering pula disebut spiritualisme, yaitu keberadaan berasal dari spiritual (ruh).

3. Keberadaan ditinjau aspek proses, kejadian, perubahan

- Mekanisme (serba mesin), paham yang berpendapat bahwa semua gejala atau peristiwa berdasarkan atas proses mekanis (mesin).

- Teleologi (serba tujuan), paham yang berpendapat bahwa semua gajala atau proses dimulai dari suatu tujuan yang berproses untuk mencapai tujuan tersebut.

- Vitalisme (daya hidup), paham yang berpendapat bahwa semua gejala atau proses tidak semata gejala fisika dan kimia saja, tapi ada aspek hidup yang tidak bisa dijelaskan dengan fisika dan kimia.

- Organisisme, paham yang berpendapat bahwa gejala atau proses merupakan suatu hubungan struktur yang dinamis, kesatuan yang memiliki bagianbagian yang berbeda dan saling berkaitan menjalin hubungan yang teratur.

\section{ONTOLOGI BISNIS}

Tsou, 2003 mendefinisikan ontologi bisnis sebagai kumpulan istilah dan definisi yang berhubungan dengan perusahaan/bisnis, seperti tujuan, proses, hal-hal yang terjadi dalam bisnis, lingkungan. (Tsou 2003). Osterwalder (Osterwalder et al. n.d.) menggambarkan ontologi bisnis dalam bentuk sebuah model, dan menjelaskan pengertiannya sebagai penawaran suatu nilai perusahaan kepada seseorang /konsumen, oleh organisasi perusahaan melalui proses membuat, memasarkan dan mendelivery dengan memanfaatkan jaringan bisnisnya untuk mendapatkan keuntungan dan keberlanjutan bisnisnya.

\section{PENGERTIAN USAHA MIKRO KECIL MENENGAH DAN FAKTA}

Usaha Mikro Kecil Menengah (UMKM) merupakan salah satu wujud dari kegiatan bisnis/usaha atau perekonomian oleh lembaga atau perorangan. Sebagaimana dijelaskan dalam definisi ontologi binis, UMKM merupakan kumpulan dari entitas (misal subyek/orang, tujuan, proses, sistem, lingkungan) yang menawarkan suatu nilai perusahaan kepada konsumen melalui proses membuat dan men-delivery dalam suatu jaringan.(Osterwalder et al. n.d.; Tsou 2003). Sementara itu beberapa lembaga memberikan definisi UMKM secara beragam, diantaranya Badan Pusat Statistik, Lementerian Negara Koperasi dan Usaha Kecil Menengah, Keputusan Menteri Keuangan, Undangundang no 20 tahun 2008. Definisi UMKM dijelaskan berbeda-beda, namun secara garis besar dikelompokan dalam tiga parameter yaitu kegiatan usaha berdasarkan jumlah tenaga kerja, aset yang dimiliki dan penghasilan penjualan (omset). Selanjutnya berdasarkan pada parameter tersebut terbentuklah pengelompokan untuk membedakan skala usaha yang meliputi Usaha skala Mikro, Usaha skala Kecil dan Usaha skala Menengah.

Badan Pusat Statistik (BPS) mendefinisikan UMKM menggunakan parameter berdasarkan jumlah tenaga 
kerja. Beberapa dasar referensi seperti Kementerian keuangan, UU no 9 tahun1995, INPRES no 10 tahun 1999, KEPPRES no 127 tahun 2001, KEPPRES no 56 tahun 2002, UU no 20 tahun 2008 mendefinisikan menurut jumlah aset yang dimiliki dan omset usaha. Definisi menurut UU no 20 tahun 2008, adalah usaha produktif orang perorang dan atau badan usaha perorangan yang memenuhi kriteria kekayaan paling banyak Rp. 50.000.000 atau memperoleh hasil penjualan (omset) setahun paling banyak Rp. 300.000.000 untuk pengertian usaha Mikro, kekayaan bersih lebih dari Rp 50.000.000 sampai dengan paling banyak Rp 500.000.000 atau memiliki hasil penjualan tahunan lebih dari Rp 300.000.000,00 sampai dengan paling banyak Rp 2.500.000.000,00 untuk pengertian Usaha Kecil, memiliki kekayaan lebih dari Rp 500.000.000 sampai dengan paling banyak Rp 10.000.000.000,00 dan memiliki hasil penjualan tahunan lebih dari Rp2.500.000.000 sampai dengan paling banyak Rp 50.000.000.000.

Kecuali versi pendefinisian yang berbeda - beda, ada beberapa persamaan karakteristik usaha mikro kecil menengah diantaranya perusahaan milik perseorangan, tenaga kerja dari keluarga sendiri dan sebagian lagi tenaga kerja dari luar keluarga, management ditangani oleh pemilik perusahaan, melakukan pembukuan keuangan secara sederhana dan terpisah dari keuangan keluarga (sumber lain menunjukkan sebagian UMKM belum melakukan pembukuan secara terpisah), modal awal berasal dari uang tabungan mereka atau dari pinjaman saudara, teman. (Glisovic \& Martinez 2012).
Seiring berdampingan dengan beberapa karakter UMKM tersebut, tidak aneh jika kemudian UMKM menghadapi beberapa problematika baik yang sifatnya internal seperti rendahnya kompetensi SDM, pemanfaatan teknologi, keterbatasan akses informasi, daya beli bahan baku yang rendah, tidak mampu menembus pasar ekspor. Juga mengahadapi permasalahan karena aspek eksternal seperti kesulitan mendapatkan sumber pendanaan, iklim usaha yang tidak menunjang, dan ancaman pasar global. Namun begitu, sekalipun menghadapi banyak hambatan, UMKM mampu menjadi pilar perekonomian bangsa. Hal ini terbukti dari UMKM mampu menyerap lebih dari $90 \%$ tenaga kerja, dan mampu menyumbang tidak kurang dari 55\% PDB.

Fakta-fakta keterbatasan dan kendala yang banyak dihadapi UMKM, menunjukkan gambaran kelemahan kemandirian dan ketergantungannya. Konsekuensi logisnya UMKM membutuhkan uluran tangan, bangunan jaringan relasi yang mampu menyangga agar UMKM tidak terpuruk.

Keterbatasan dan kendala yang dimiliki oleh UMKM menuntut UMKM harus mampu menyeimbangkan dan memenuhi kebutuhannya dengan mengupayakan dari sumber daya lain. Sebagai contoh keterbatasan akses pendanaan dan sumber informasi justru merangsang UMKM membangun model manajemen sekalipun sederhana namun memiliki kekuatan ikatan kerja yang sangat baik melalui hubungan kerja kekeluargaan, gotong royong, kebersamaan. Iklim kerja dalam bisnis UMKM tidak dibangun sebagaimana idealnya sebuah perusahaan yang mapan dan besar, namun dibangun dengan mengikuti 
naluri budaya komunitas dilingkungan mereka. Sehingga harmoni antara iklim kerja dengan norma kehidupan masyarakat justru menjadi terbentuk. Kesederhanaan pola pikir pemilik usaha dan keterbatasan sumber daya, menyebabkan mereka tidak berorientasi pada bisnis yang membutuhkan teknologi dan kompetensi SDM yang tinggi, sehingga pada gilirannya bisnis pada UMKM mampu menyerap tenaga kerja yang banyak karena tidak menuntut kualifikasi SDM yang tinggi. Dipandang dalam sudut tinjauan pemecahan masalah negara dan bangsa, terutama dalam permasalahan keterserapan tenaga kerja, fenomena UMKM mampu menyerap lebih dri $90 \%$, menunjukkan UMKM merupakan suatu model yang memiliki nilai fungsi, dalam hal ini menjadi problem solver masalah pengangguran. Di sisi lain UMKM yang pada umumnya berupa bangunan manajemen yang sederhana, namun terikat dalam hubungan kerja yang bersifat kekeluargaan, gotong royong dan suasana kebersamaan menjadikan UMKM sebuah wadah bisnis yang tahan banting dan tahan terhadap terpaan krisis. UMKM justru menjadi wadah bertemunya modal sosial yaitu kebersamaan, kekeluargaan, gotong royong yang diterapkan dalam ranah bisnis. UMKM menjadi lembaga yang memiliki nilai fungsi sebagai wadah penerapan dan pelestarian modal sosial tersebut, yang tidak lain adalah ciri dan karakter bangsa Indonesia.

UMKM merupakan kegiatan bisnis dimana posisinya menjadi bagian dari jaringan bisnis yang lebih besar. Setiap perubahan yang terjadi pada lingkungan bisnis bisa dipastikan akan berpengaruh terhadap bisnis UMKM. Perubahan yang terjadi pada UMKM akibat adanya perubahan lingkungan bisnis, merupakan wujud respon ataupun antisipasi UMKM dalam rangka beradaptasi diri, mempertahankan keberlangsungan hidupnya. UMKM tidak bisa mengambil sikap statis. Disadari ataupun tidak UMKM harus mengambil sikap beradaptasi secara dinamis. Ditilik dari sifat naluri, bahwa bisnis harus bisa berjalan dan meneruskan kelangsunga hidup, mendaulat UMKM harus mampu bersaing. Namun hal itu tidak dapat diartikan bahwa dengan dalih untuk kelangsungan hidup kemudian UMKM menggunakan caracara yang bertentangan denga etika moral. Upaya kegiatan bisnis tetap harus memperhatikan kode etik moral.

Potensi strategis, istilah yang paling tepat untuk menyebutkan potensi yang dimiliki UMKM baik yang melekat dalam karakter UMKM maupun potensi dalam bentuk reaksi UMKM terhadap kendala yang dihadapinya. MPR memandang penting potensi ini sebagai modal penting bagi bangsa Indonesia. MPR menuangkan amanahnya di dalam TAP MPR no XVI/MPR-RI/ 1998 tentang Politik Ekonomi mengamanatkan dalam rangka Demokrasi Ekonomi, Usaha Mikro, Kecil dan Menengah perlu diberdayakan karena memiliki potensi strategis.

\section{ONTOLOGI UMKM}

Refleksi ontologi UMKM Indonesia dimaksudkan upaya untuk merenungkan realitas UMKM dari kaca mata persoalan mendasar ontologi. Pada bagian sebelumnya telah dituangkan delapan persoalan mendasar ontologi. Dari kedelapan persoalan mendasar tersebut kiranya yang relevan untuk mere- 
fleksikan realitas UMKM Indonesia adalah dimensi persoalan kuantitas, kemandirian, dinamika proses, dan dimensi arti-nilai.

Mengawali refleksi ontologi
UMKM, perlu mengutip ulang pengertian UMKM pada bagian di atas, yaitu UMKM merupakan model berupa kumpulan dari entitas (istilah) yang memberikan penawaran suatu nilai perusahaan kepada konsumen melalui proses membuat, memasarkan, men-delivery dengan memanfaatkan jaringan bisnisnya untuk mendapatkan keuntungan. UMKM merupakan salah satu wujud dari bentuk bisnis. Untuk mulai mengungkap ontologi UMKM, pertanyaan mendasar yang muncul adalah apakah UMKM itu berjumlah banyak atau tunggal. Sebagaimana pengertian UMKM yang terdefinisi di atas, UMKM merupakan kumpulan/kesatuan dari entitas-entitas seperti orang, tujuan, proses, sistem yang saling berhubungan erat satu sama lain dalam rangka untuk mencapai tujuan bisnis dengan menawarkan nilai perusahaan kepada konsumen, dengan kata lain berupa organisasi. Kegiatan bisnis ini dilakukan dengan melalui proses membuat, men-delivery dengan memanfaatkan jaringan bisnis. Selama berlangsungnya proses, UMKM berinteraksi dengan lingkungan bisnis, persaingan. UMKM tidak bisa berdiri sendiri tanpa membangun relasi dengan unit bisnis lain. Konsekuensi dari proses berinteraksi dengan lingkungan bisnis, UMKM akan selalu mengalami perubahan karena membutuhkan kemampuan beradaptasi.

Sesuai dengan nama yang disandangnya, istilah usaha mikro kecil menengah, mengandung pengertian keterbatasan sumber daya. Sehingga keberlangsungan hidup UMKM membutuhkan uluran tangan mengatasi keterbatasan ini. Namun begitu justru dalam keadaan keterbatasan sumber daya, UMKM terkondisi membangun model manajemen yang memiliki kekuatan ikatan kerja melalui hubungan kerja kekeluargaan, gotong royong dan kebersamaan. UMKM juga mampu membangun iklim kerja berdasarkan pada naluri budaya komunitas di lingkungan mereka.

\section{Ontologi Dimesi Kuantitas}

Dalam kajian ontologi, persoalan kuantitas berkaitan dengan pertanyaan UMKM itu entitas tunggal atau jamak. Mengacu dalam pengertian UMKM sebelumnya dimana UMKM dipahami sebagai model berupa kumpulan entitas yang memberikan penawaran suatu nilai perusahaan kepada konsumen melalui dinamika proses dengan memanfaatkan jaringan untuk memenuhi tujuan bisnis. Pemenggalan secara parsial definisi tersebut, dalam frasa 'model berupa kumpulan entitas' membawa kepada pengertian kuantitas tunggal (kesatuan). Kuantitas tunggal ini sering dikenal dengan istilah organisasi, yaitu organisasi bisnis. Namun jika pemenggalan secara parsial yang lain dari defini tersebut, dalam frasa 'memanfaatkan jaringan bisnisnya', akan membawa kepada pengertian bahwa kumpulan entitas tersebut akan menjadi bagian dari suatu jaringan yang lebih besar, yang sering dikenal dengan istilah jaringan industri. Dalam sudut pandang ini dimensi UMKM akan dipahami sebagai kuantitas jamak. Dengan demikian muncul dua pengertian pandangan UMKM sebagai realita tunggal dan sebagai realitas 
jamak. Perbedaan yang muncul dalam pemahaman ontologi dari sisi dimensi kuantitas, sebenarnya tidak perlu dirisaukan maupun untuk diperdebatkan, karena perbedaan ini muncul akibat perbedaan sudut pandang. Sehingga yang perlu dipahami adalah perbedaan ini menjadi relativitas dalam cara memandang dan memahami ontologi UMKM dalam dimensi kuantitas.

\section{Ontologi Dimensi Kemandirian}

Ontologi dimensi Kemandirian memandang UMKM dari persoalan otonomi-korelasi, yaitu memandang UMKM sebagai realita yang memiliki otoritas ataukah realita yang memiliki ketergantungan dalam suatu relasi.

Memandang realita UMKM dari dimensi Kemandirian tidak bisa lepas dari dimensi kuantitas UMKM. Apakah kuantitas tersebut tunggal atau jamak. Masing-masing jawaban akan mengarah kepada pengertian otonomi dan korelasi. UMKM memiliki dimensi kuantitas tunggal sekaligus jamak. Jika realita difahami bersifat tunggal maka harus mampu menjelaskan dimensi otonomi dari entitas tersebut. Sebaliknya jika realita difahami bersifat jamak maka harus mampu menjelaskan hubungan antara UMKM yang satu dengan UMKM lainnya.

UMKM merupakan salah satu bentuk pelaku bisnis. Masing-masing pelaku bisnis memiliki otoritas untuk menentukan arah tujuan sendiri, pengambilan keputusan sendiri. Masing-masing entitas memiliki otonomi menentukan nasibnya sendiri. Namun begitu dalam mencapai tujuannya, entitas pelaku bisnis tidak bisa berdiri sendiri. Antara satu entitas berhubungan dan bergantung dengan entitas lainnya. Dalam hubungan rantai ekonomi, keberlangsungan hidup pemasok bergantung kepada produsen atau sebaliknya, entitas produsen bergantung kepada konsumen atau sebaliknya. Hubungan ini merupakan korelasi yang tidak dapat dipisahkan. Bilamana terdapat kepincangan pada salah satu entitas, akan mempengaruhi keberlangsungan entitas yang lain. Berangkat dari pemahaman ini, maka jika dipandang dari dimensi kuantitas, UMKM masuk dalam kategori jamak dimana masing-masing UMKM saling berinteraksi dalam hubungan saling ketergantungan. Sehubungan dengan realita UMKM memiliki sifat ganda yaitu sifat tunggal sekaligus jamak maka UMKM juga memiliki sifat otoritas sekaligus korelasi. Namun begitu dalam memecahkan persoalan ontologi otoritas-korelasi ini, perlu dipastikan arah kecenderunga sifat UMKM. Untuk memperjelas kemana arah kecenderungan sifat UMKM maka perlu dibedakan ranah pandangan dalam pemahaman otoritas korelasi UMKM, yaitu ranah pandangan realis dan idealis. Ranah pandangan realis dimaksudkan sebagai ranah pandangan UMKM dari kenyataan UMKM; sedangkan ranah pandangan idealis dimaksudkan sebagai ranah pandangan UMKM bagaimana seharusnya.

Berkaitan dengan pandangan realis, UMKM merupakan entitas pelaku bisnis yang memiliki keterbatasan kapabilitas dan kapasitas, sebagaimana penamaan yang disandangnya yaitu Usaha Mikro Kecil Menengah, yang memberikan arti keterbatasan dalam 
skala kapabilitas dan kapasitasnya. Dalam pemahaman ini, UMKM memiliki keterbatasan dalam besaran sumber daya yaitu sumber daya manusia, sumber daya keuangan, sumber daya teknologi, sumber daya informasi. Berkaitan dengan pandangan idealis, UMKM semestinya menjadi bentuk bisnis yang mampu menopang kehidupan masyarakat, mengentaskan kemiskinan, membantu menyelesaikan masalah pengangguran, dan menjadi pilar perekonomian negara.

Perbincangan persoalan sifat otoritas-korelasi, membawa pada ranah level skup yang berbeda. Perbincangan dimensi otoritas menjadi topik yang dikaji dalam skup level individu pelaku bisnis / entitas, sementara dimensi korelasi menjadi topik yang dikaji dalam skup level industri. Dalam skup perbincangan manajemen dan ekonomi, perbincangan dimensi otoritas berada pada ranah mikro, sementara perbincangan dimensi korelasi berada pada ranah makro. Hal penting yang perlu digarisbawahi bahwa perbincangan kedua sifat tersebut tidak bisa saling lepas.

\section{Ontologi Dimensi Dinamika Proses}

Ontologi dinamika proses melakukan refleksi atas realita UMKM untuk menjawab pertanyaan apakah realita UMKM mengalami dinamika proses perubahan ataukah bersifat entitas yang statis, tidak berubah. Dinamika proses perputaran hidup adalah: lahir, tumbuh kemudian mati. Tujuan dari perbincangan bagaimana hakekat UMKM dan bagaimana UMKM semestinya dari sisi pandang dimensi dinamika proses, adalah agar ketika UMKM lahir, kepadanya diharapkan akan mampu berkembang dan dapat hidup selama mungkin. Secara sederhana dapat dikatakan bagaimana mengupayakan supaya UMKM dapat lahir, berkembang dan tetap bertahan hidup tidak mengalami kebangkrutan.

Pada saat awal sekali pelaku bisnis UMKM memulai bisnisnya dapat dikatakan pelaku bisnis UMKM sedang mengawali keberadaannya dari 'belum melakukan' menjadi 'melakukan', dari 'ketiadaan' menjadi 'yang ada'. Selama proses mempertahankan keberadaannya, pelaku bisnis UMKM melakukan proses dinamika interaksi dan berhubungan dengan entitas / pihak lain. Lazimnya makhluk hidup mempertahankan hidupnya dengan cara beradaptasi, pada saatnya tidak mampu lagi beradaptasi maka akan mengalami 'ketiadaan' (kebangkrutan). Terutama bila ditinjau dalam posisinya, UMKM merupakan kegiatan bisnis yang menjadi bagian dari jaringan bisnis yang lebih besar, yaitu lingkungan bisnis. Perubahan yang terjadi pada lingkungan bisa dipastikan akan berpengaruh terhadap bisnis UMKM. Dalam rangka mempertahankan kelangsungan hidupnya, UMKM harus mampu beradaptasi menyesuaikan diri dengan perubahan lingkungan. Dengan kata lain UMKM yang masih mampu bertahan hidup adalah UMKM dinamis. Melalui pemahaman ini, maka ontologi UMKM ditijau dari dimensi dinamika proses, UMKM adalah realita dinamis, realitas yang selalu berproses.

\section{Ontologi dimensi Arti dan Nilai}

Ontologi dimensi arti dan nilai adalah persoalan yang terkait dengan pertanyaan apakah realita UMKM memiliki 
arti dan nilai. Dimensi arti adalah persoalan yang mempertanyakan apakah realita UMKM memiliki fungsi guna. Dimensi nilai adalah persoalan yang mempertanyakan apakah realita UMKM memiliki sesuatu yang dipersepsikan baik atau buruk oleh masyarakat. Sudah menjadi fakta UMKM mampu menyerap 90\% tenaga kerja. Potensi ini bukan kebetulan semata, UMKM memiliki model ikatan hubungan kerja yang kuat, kekeluargaan, gotong royong, kebersamaan serta mampu membangun harmoni antara iklim kerja ditempat kerja dengan norma kehidupan dilingkungan sekitanya.

\section{a. Nilai Kebersamaan}

Kebersamaan (mutualisme), suatu doktrin yang menempatkan independensi elemen-elemen sosial sebagai penentu hubungan-hubungan individu dan sosial, dimana kegiatan kolektif diikat oleh sentimen kekeluargaan yang menumbuhkan semangat saling tolong menolong, saling menghormati dan saling mengutamakan kepentingan bersama. Kebersamaan menjadi prinsip utama dalam mencapai tujuan organisasi, perusahaan, bisnis. Nilai kebersamaan ini menjadi jawaban mengapa UMKM mampu menanggung beban berat akibat keterbatsan sumber daya. Nilai kebersamaan menjadi komponen substitusi terhadap beberapa komponen biaya yang dibutuhkan dalam kehidupan UMKM.

\section{b. Nilai Kekeluargaan}

Rasa kekeluargaan adalah suatu prinsip atas asas dalam hidup bersama ibarat sebagai keluarga, masing-masing terjalin dalam satu hati, saling mengasihi, saling menerima perbedaan, menjaga keutuhan kesatuan, mengutamakan keyakinan bersama tanpa mengabaikan keyakinan masing-masing. Kekeluargaan bisa menjadi jaminan terhindarnya perpecahan organisasi karena konflik dan penyelesaian konfrontasi. Nilai kekeluargaan menjadi dasar kesatuan organisasi. Sifat kekeluargaan banyak ditemui di perusahaan dalam skala UMKM.

\section{c. Nilai gotong royong}

Gotong royong merupakan penyatuan dari kombinasi kebersamaan, kekeluargaan yang terwujud dalam bentuk aktifitas. Melalui gotong royong, hambatan dan tantangan lingkungan eksternal organisasi niscaya untuk dihadapi, sekalipun hanya berbekal modal dan fasilitas yang minim. Nilai gotong royong memotivasi individu untuk struggling, creative, sehingga dapat membantu perusahaan dalam menghemat biaya. Sifat gotong royong menjadi modal sosial dalam UMKM, sifat gotong royong menjadi kebutuhan untuk mensubstitusi tuntutan ketercukupan modal finansial yang pada umumnya justru menjadi kelemahan UMKM.

\section{IMPLIKASI}

Globalisasi adalah proses sosialkomunitas yang tidak dapat dihindari. Apalagi dengan disahkannya UU no 7 tahun 1994 tentang Pengesahan Persetujuan Pembentukan Organisasi Perdagangan Dunia, yang menandai ikut sertanya Indonesia berbaur dalam dinamika dan mekanisme perdagangan dunia, secara implisit menggambarkan adanya pembauran bangsa dari luar masuk ke 
dalam ranah kehidupan ekonomi dalam negeri. Banyak ancaman yang akan merubah tatanan kehidupan bangsa, mempersempit kesempatan berpenghidupan layak bagi masyarakat yang memiliki keterbatasan potensi. Bahkan UUD 1945 setelah mengalami amandemen, pada pasal 33 dengan menambahkan pasal baru mengenai perekonomian nasional, belum bisa menjawab tantangan globalisasi. UU no 20 tahun 2008, didalamnya belum ada pasal yang secara eksplisit mengatur bagaimana keberadaan UMKM dalam liberalisasi ekonomi (Komarudin 2014) (p 7). Globalisasi yang bersifat destruktif layaknya perlu ditangkal. Sri Edi Swasono, menjelaskan bangun sistem sosial-ekonomi kemasyarakatan yang paling ampuh untuk menghadapi ancaman globalisasi yang bersifat destruktif adalah sifat-sifat kesatuan yaitu persatuan, kebersamaan, gotong royong, kekeluargaan. Sehingga sistem sosial dengan asas persatuan, kebersamaan, gotong royong dan kekeluargaan akan mampu menghalau ancaman sosial-budaya masyarakat. Dengan sistem ekonomi berasaskan persatuan, kebersamaan, gotong royong dan kekeluargaan akan mampu menghadapi tekanan kapitalisme, liberalisme, atau faham-faham ekonomi berbasis individualis, yang sering disebut sebagai Demokrasi Ekonomi. (Swasono 2014)

1. Meskipun kental dengan berbagai keterbatasan, UMKM di Indonesia ternyata mampu menjadi tulang punggung perekonomian bangsa Indonesia dalam menghadapi badai krisis ekonomi, dimana hal ini diduga karena peran karakter bangsa Indonesia, yaitu nilai-nilai kebersamaan, persatuan, gotong royong masih melekat dalam tata kelola UMKM (skala mikro) di Indonesia. Namun, sekalipun telah terbukti mampu menjadi tulang punggung perekonomian, UMKM di Indonesia berjalan tertatih tatih. Kemampuannya sebagai pilar penyangga hanya untuk bertahan saja, sulit diharapkan untuk bisa berkembang. Kemampuan bertahan tentunya ada batasnya, sehingga tidak mungkin mengharapkan keadaan semacam itu untuk jangka panjang. Untuk lebih memperkokoh daya tahan internal serta sebagai jaminan keberhasilan dalam meraih cita-cita dan pelaksanaan bisnis perusahaan, pelaku UMKM perlu memuatkan nilai norma sosial dan etika moral dalam pengelolaan perusahaannya, melaksanakan kegiatan operasional bisnisnya mengggunakan prosedur dan sistem tata kelola perusahaan yang baik.

2. UMKM memiliki potensi strategis, sehingga perlu mendapatkan perlindungan. Untuk mewujudkan upaya perlindungan, MPR melalui amanah dalam Ketetapan no XVI/MPRRI/1998 tentang Politik Ekonomi dalam rangka menciptakan Demokrasi Ekonomi UMKM perlu diberdayakan. Upaya yang perlu ditempuh adalah dengan menciptakan iklim usaha yang sesuai dengan karakter UMKM Indonesia, yang notabene juga merupakan karakter bangsa Indonesia. Negara perlu melakukan upaya proaktif,s ebagaimana termaktub dalam UUD 1945 pasal 33:

...... (1) perekonomian disusun sebagai usaha bersama berdasar atas asas kekeluargaan, (2) Cabang-cabang produksi yang penting bagi negara dan yang menguasai hajat hidup orang banyak dikuasai oleh negara, (3) bumi dan air dan kekayaan alam yyang terkandung dida- 
lamnya dikuasai oleh negara dan dipergunakan untuk sebesar-besarnya kemakmuran rakyat, (4) perekonomian nasional diselenggarakan berdasar demokrasi ekonomi dengan prinsip kebersamaan, efisiensi berkeadilan, berkelanjutan, berwawasan lingkungan, kemandirian, serta dengan menjaga keseimbangan kemajuan dan kesatuan ekonomi nasional.......

Secara implisit mengandung makna, bahwa perekonomian harus diatur oleh pemerintah, tidak dibiarkan tersusun sendiri melalui mekanisme dan kekuatan pasar. (Sri Edi; 2014) selanjutnya masih oleh Sri Edi, peran negara tidak sebatas mengintervensi, tetapi menata, mendesain wujud, dan menstruktur, untuk mewujudkan bangun kebersamaan dan asas kekeluargaan serta terjaminnya keadilan sosial bagi seluruh rakyat Indonesia. Oleh karena itu perencanaannya haruslah dilakukan secara terintegrasi secara nasional.

Pembangunan harus mampu menciptakan iklim usaha, tidak diserahkan pada kehendak pasar dan selera pasar, tapi harus disusun oleh negara. Pasar dalam konteks kontemporer mencerminkan keinginan pemilik modal yang kuat. Bidang-bidang produksi / usaha yang menyangkut kehidupan orang banyak dan sumber daya alam yang menjadi kebutuhan hajat hidup orang banyak dikuasai dan dikelola oleh negara.

3. Peran dalam membangun struktur ekonomi memang menjadi tanggung jawab pemerintah, namun untuk merealisasikannya menjadi tanggung jawab semua pihak, termasuk masyarakat dan pelaku UMKM.

\section{DAFTAR PUSTAKA}

Abidin, A., Usaha Micro Kecil Dan Menengah (jurnal).

Ahmad Mardalis, M. Sholahuddin, W.D., Penerapan Teknologi Internet Sebagai Sarana Promosi Pada Usaha Kecil Dan Menengah Yang Berorientasi Ekspor.

Fadland, D., Herawati, N. \& Hardilina, 2013. Implementasi Program Fasilitasi Pengembangan Usaha Mikro Melalui Kegiatan Kemasan Di Dinas Koperasi Dan Umkm Kabupaten Kubu Raya. pp.1-11.

Fang, X. et al., 2013. Predicting Adoption Probabilities in Social Networks. Information Systems Research, 24(1), pp.128-145. Available at: http://dx.doi.org/10.1287/isre.1120 .0461 .

Glisovic, J. \& Martinez, M., 2012. What Role for Microfinance. (Ifc 2010). Available at: http://www.cgap.org/sites/default/f iles/CGAP-Focus-Note-FinancingSmall-Enterprises-What-Role-forMicrofinance-Jul-2012.pdf.

Hamid, E.S., 2010. Pengembangan Umkm Untuk Meningkatkan Pertumbuhan Ekonomi Daerah. In pp. 1-5.

Haryani, E., Accounting System For Small Business In Indonesia ( Case Study Convection Business In Tingkir Lor Village ). 2(April 2012), pp.104-112.

Hoed, B.H., 2001. Dari logika tuyul ke erotisme, IndonesiaTera. Available at: https://books. google.co.id/books?id=lorJS6oZyd IC.

Kasus, S. et al., 2011. Universitas Indonesia Sistem Kemitraan Usaha 
Mikro Kecil Menengah ( Umkm ) Usaha Besar Dengan Pemodelan.

Khhotimah, T. \& Fiati, R., 2013. Peningkatan Keunggulan Kompetitif Pada UMKM Gerabah Melalui Model E-Business. 3(1), pp.31-40.

Komarudin, A., 2014. Politik Hukum Integratif UMKM 1st ed. Mustofa, ed., RMBOOKS.

Moon, S.M., 2006. UNIFICATION 1st ed., Tokyo Japan: Kogensha 37-18 Udagawa-cho,Shibuya-Tokyo Japan.

Muhammad, R. \& Kusuma, H., 2014. The Need for Accounting Information System to Facilitate Partnership Contracts in Islamic Microfinance Institutions: The Case of Baitul Maal wa Tamwil ( BMT ) in Indonesia. 4(7), pp.592605.

Osterwalder, A. et al., An e-Business Model Ontology for Modeling eBusiness.

Purnomo, M., 2011. Adopsi Teknologi Oleh Usaha Mikro Kecil Menengah. Jurnal Dinamika Manajemen, 2(2), pp.109-117.

Ramdhansyah \& Silalahi, S.A., 2013. Pengembangan Model Pendanaan UMKM Berdasarkan Persepsi UMKM. Jurnal Keuangan dan Bisnis, 5(1).

Rumanti, A.A. \& Syauta, K.J., 2013. Determining Strategies Based on Strategic Position Analysis in Small and Medium Enterprises. 3(4).

Sinaga, S., 2013. Management And Programs Of Intellectual Property government or foreign agencies. Intellectual Property Rights ( IPRs ) that Potentially Affect SMEs in Indonesia Several studies have found that industries with large scale research and development ( $\mathrm{R}$ \& D. 6(2), pp.615-636.

Suandi, E. \& Susilo, Y.S., 2011. Strategi Pengembangan Usaha Mikro Kecil Dan Menengah Di Provinsi Daerah Istimewa Yogyakarta *. 12, pp.4555.

Sudarto, S., Suroso, A. \& Jati, D.P., 2013. Potential and Problems of Small Medium Enterprise (SMEs) Coconut-Sugar: Case Study in Banyumas Regency, Central Java Indonesia. International Journal of Business and Management, 8(3), pp.18-27. Available at: http://www.ccsenet.org/journal/ind ex.php/ijbm/article/view/22377

[Accessed November 1, 2014].

Suryana, Y., 2012. Integrated Model of Micro Financial Institutions andMicro Small Enterprises. International Journal of eEducation, e-Business, eManagement and e-Learning, 2(5). Available at: http://www.ijeeee.org/show-33398-1.html [Accessed November 1, 2014].

Sutikna, N., 2013. Dimensi Ontologis Kebebasan Menurut Erich Fromm Relevansinya Dengan Pengembangan PERS Indonesia, Purwokerto.

Suyatna, H., Reorientasi Kebijakan UMKM di Era Asia China Free Trade Area ( ACFTA ).

Swasono, S.E., 2014. Menegakkan Demokrasi Ekonomi 1st ed., Jakarta.

Tsou, J., 2003. The Implementation of ECommerce Ontology. pp.1-16. 